\title{
Institusionalisme - springlewendig in die kwynende Afrikaanse Gereformeerde kerkpraktyk
}

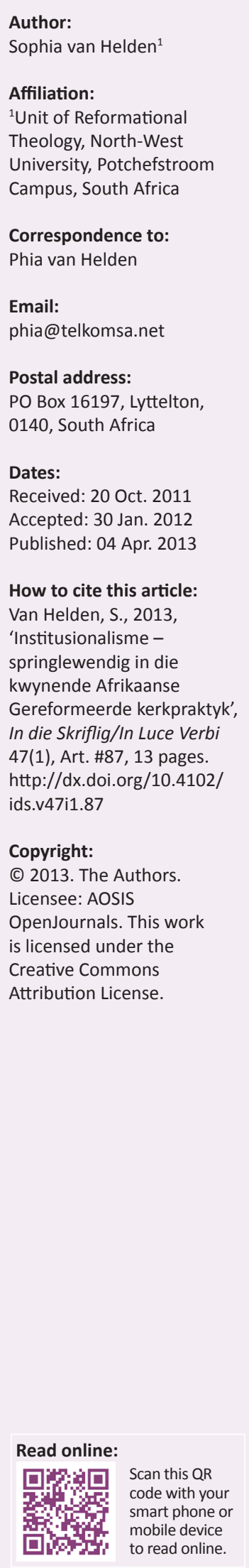

In hierdie artikel word die institusionalistiese denkwyse (I-denke) as dominante denkwyse in die krimpende tradisioneel-Afrikaanssprekende Gereformeerde kerke bespreek. I-denke toon 'n denkwanbalans wat weerspieël word in die huidige ongebalanseerde en ongesonde kerkpraktyk. Die onwaarskynlikheid van organiese groei binne die huidige ekklesiologiese wanbalans, word belig deur te fokus op navorsing binne die Gereformeerde Kerk van Suid Afrika (GKSA)-kerkpraktyk, as een van die drie gereformeerde susterskerke. Die bevindings dui op die noodeisende toestand binne die tradisionele ekklesiologie. Die Christosentriese denkparadigma word as gebalanseerde korrektief aan die hand van die groot opdrag uiteengesit (maak dissipels van alle nasies) uiteengesit, as sleutel vir die daarstel van gesonde omstandighede ter wille van kerkgroei. Denke as die belangrikste ekklesiologiese oorsaak van kerkkrimping, kan deur denkverandering teëgewerk word ten einde verdere krimping van die susterskerke teë te werk.

Institutionalism - alive and well in the declining Afrikaans reformed church practice. This article discusses institutionalism as the dominant paradigm (I-paradigm) among the declining traditional Afrikaans speaking Reformed churches in South Africa. The I-paradigm portrays imbalanced thinking prevailing in the current unhealthy church practice. The improbability of natural growth within the recent ecclesiastic imbalance, is highlighted by focusing on a study within the church practice of the Reformed Curch of South Africa (RCSA) - one of the three reformed sister churches. Conclusions drawn from the study emphasise the serious conditions of this traditional ecclesiology. The Christ centered paradigm, as balanced corrective, is discussed in line with the great commission (disciple the nations) as key to creating healthy circumstances in order to realise church growth in the long run. Thinking, as the most important ecclesiological factor causing church decline, can be changed, thus preventing further decline of the sister churches.

\section{Inleiding}

Institusionalistiese denke (vgl. Schwarz 1999:24-42, 191-194) en die daaruit voortspruitende institusionalistiese kerkpraktyke, is opvallend sterk gevestig binne die Afrikaanssprekende gereformeerde susterskerke. ${ }^{1}$ Literatuurstudie en bevindings na aanleiding van 'n steekproef rakende I-denke in die tradisionele kerkpraktyk toon dat die meeste gereformeerde gelowiges werklik onbewus is van die verband tussen hierdie twee sake, naamlik die institusionalistiese denkwyse en die krimpende kerke (vgl. Hendriks 1996; 1999; 2003; Oliver 2007:23-40).

Die problematiese toedrag binne die tradisioneel Afrikaanssprekende hoofstroomkerke vra derhalwe om dringende selfondersoek, ten einde bewus te word van die werklike toedrag van die heersende krimpende fase; ' $n$ toestand wat roep om ernstige herbesinning en radikale bekering deur diepgaande denkverandering (vgl. Gilbert 2004; McLaren 2006:44; Nel 2009; Pretorius \& Lindeque 2009; Saarinen 1992; Tickle 2008). 'n Denkverandering kan die betrokke gereformeerde kerke op'n pad van ware Skrifgehoorsaamheid plaas (vgl. McLaren 2006:226). 'n Denkverandering kan die huidige dalende kurwe (communitas-fase) betyds begin omkeer na 'n stygende kurwe (societas-fase) (Burger 1995:13, 23-26; De Wet 2000:7; Hendriks 1996:143; 1999:19; Roxburgh 1997:27-29; Saarinen 1992:23; Tickle 2008:121-122). 'n Radikale,Skrifgehoorsame denkverandering en omkeer is die enigste uitweg (Gilbert 2004:2; Nel 2009:76; Pretorius \& Lindeque 2009; Tickle 2008:143) en anker om nie weens ongebalanseerde of ongesonde denkwyses in die afwaartse golffase te verdwyn nie (Brouwer et al. 2007:16-20, 105; Saarinen 1992); 'n afwaartse kurwe wat voortgestu word deur die huidige, steeds toenemend 'anderse' (Brouwer et al. 2007:183; Hendriks 2003; Jenkins 2006:254; Tickle 2008:13-17, 135) eise van die oorgangstyd. Die oorgangstyd word

1.Die susterskerke is die drie susterskerke, naamlik die Gereformeerde Kerke in Suid-Afrika (GKSA), die Nederduitsch Hervormde Kerk (NHK) en die Nederduitse Gereformeerde Kerk (NGK) het tradisioneel in dieselfde tydperk ontstaan, deel dieselfde geskiedenis en besig Afrikaans as voertaal (Hofmeyr \& Pillay 1994:113-115, 309-311). 
daargestel deur die onafwendbare, allesveranderende 500-jaarlikse gelykmakende en verskuiwende golf wat tans binne die Christendom beleef word (Brouwer et al. 2007: 16-20, 105; De Klerk \& Van Helden 2011; Saarinen 1992:1-23; Tickle 2008:1-33, 47, 59-61, 123-150).

\section{Institusionalisme as ongebalanseerde en ongesonde denkwyse}

Binne ' $n$ denkparadigma is daar altyd twee pole, naamlik die dinamiese en die statiese pole. Die twee pole moet in balans met én ter wille van mekaar funksioneer (Brouwer et al. 2007:176). Indien slegs op die een pool gefokus word, ontstaan 'n tiperende denkwyse wat van wanbalans spreek en wat op die lang duur nie volhoubaar is nie. Die twee denkrigtings wat volgens hierdie twee pole ontwikkel het, word deur die tradisionele stroom en die charismatiese stroom $^{2}$ verteenwoordig - onderskeidelik deur die institusionalistiese denkwyse (voortaan: I-denke) en die spiritualistiese denkwyse (voortaan: S-denke).

I-denke, ook bekend as Monisme, lê eensydig die klem op organisatoriese aspekte en word ook as hard, manlik, rasioneel, analities, nie-animaties, tegnologies en deduktief beskryf (Schwarz 1999:14-48, 71, 218-220). Hierteenoor lê die S-paradigma, ook bekend as Dualisme, klem op organiese aspekte en word as sag, animaties, biologies, intuïtief, vroulik, holisties en induktief beskryf. By elkeen van die twee strome manifesteer die gepolariseerde pole in 'n ongebalanseerde en ongesonde kerkpraktyk. Gebalanseerde en gesonde groei is slegs teenwoordig wanneer die statiese element effektief en in harmonie met die dinamiese element funksioneer. Die wêreldtendens blyk dat daar toename in die spiritualistiese paradigma is, terwyl die institusionalistiese paradigma, ook in Suid-Afrika, blykbaar aan die afneem is (Du Toit 2000:58 e.v.; Hendriks 1999:18; Niemandt 2007:12, 23, 39; Smit \& Vorster 2000:520).

Die verskynsels van krimpende gemeentes kan geïnterpreteer word as die resultaat van I-denkendes wat onnadenkend tevrede is met ' $n$ gevestigde, gestagneerde institusionalistiese ekklesiologie (Botha 2006:47; Burger 1999:148; Du Toit et al. 2002:44-45, 49; Schalekamp 2005a:24). Die uitgangspunt in diesusterskerke kan geïnterpreteer word as institusionalisme gegrond op die Woord. Ordelikheid en die suiwer Woord is die susterskerke se fokuspunt, in so 'n mate dat gereken word dat geen aspek van die ekklesiologie waarmee gewerk word, bevraagteken kan word nie. Schwarz (1999:7) beskryf mense wat so dink as mense wat hulle eie siening beskou as iets wat 'beyond question' is. Hierdie fokuspunt dra soveel

2.Charismatiese stroom: Die waarheid is in ervaring en manisfestering van die Gees geleë, met ander woorde, die Woord plus iets meer: Die krag van Christus is nie hiervolgens die kern nie, maar wel die krag van die sigbare teken. Sekerheid
word deur die sigbare teken verkry (Green 2004:289, 327). Gawes word letterlik verstaan en geldig gehou vir enige tydvak (Green 2004:264-275, 286, 289; McGrath 2005:193-194; Williams 2005:571). Menslike aksie en persoonlike belewing, saam 2005:193-194; Williams 2005:571). Menslike aksie en persoonlike belewing, saam
met die vrye werking van die Gees, soos dit veral tot uiting kom in die erediens, is met die vrye werking van die Gees, soos dit veral tot uiting kom in die erediens, is
die uitgangspunt (Green 2004:151; Malphurs 2004:23, 24; McGrath 2005-215; Van der Spuy 1998:119, 156; Warren 2005). Rakende opleiding word gemeen dat die Gees deur die rasionele van die akademie uitgeblus kan word en dat belewing nie Gees deur die rasionele van die akademie uitgeblus kan word en dat bel
dogma nodig het nie (McGrath 2005:193-197; Williams 2005:563-573). gewig dat die balans versteur word en daarom word hierdie sterk punt die susterskerke se swak punt.

Volgens Efesiërs 4, Romeine 12 en 1 Korintiërs 12 word die kerk as lewende organisme beskou. Kuyper (1910:26-27; Dreyer 2009:27) het vantevore reeds daarop gewys dat indien die kerk nie as organisme funksioneer nie, met ander woorde nie gebalanseerdheid en gesondheid in denke en praktyk vertoon nie, verval in die kerk sal toeneem en institusialisme sal bly domineer.

\section{Steekproef rakende I-denke in die tradisionele kerkpraktyk}

Sedert 1990 is krimping as tendens in die susterskerke in SuidAfrika bevestig (Hendriks 1993:545). Die talle oorsake van die krimpende tendens by tradisioneel Afrikaanse susterskerke, is sedertdien deur verskeie navorsers ondersoek (o.a. Dreyer 2009:7; Du Toit et al. 2002:47, 49; Niemandt 2007:40; Van der Spuy 1998:41; Van der Walt 2006:31; Van Helden 2010). Telkens is bevind dat geblokkeerde denke as interne faktor binne I-denke, die hoofoorsaak blyk te wees. Die skrywer van hierdie artikel het geblokkeerde denke, asook die intensiteit van I-denke binne die susterskerke is aan die hand van 'n steekproef binne die GKSA ondersoek.

\section{Vraelys aan die hand van Schwarz se benadering van die kerkpraktyk}

Die steekproef is aan die hand van 'n vraelys (vgl. Bylaag 1) gedoen. Die vraelys is opgestel nadat 'n uitgebreide literatuurstudie gedoen is en tersaaklike gegewens geplaas is binne die raamwerk van Schwarz (2000) se benadering van die kerkpraktyk. In ander benaderings soos dié van Callahan en Warren, word sekere van Schwarz se kwaliteitskenmerke in 'n mindere of meerdere mate herken (De Kock 2003). Die tydlose Skrifbeginsels of waarhede waarmee Schwarz werk, geniet wêreldwyd egter toenemend voorkeur bo ander benaderings. Schwartz se benadering leen hom sonder weerga tot ' $n$ volkome omvattende, geskikte en Skrifgetroue raamwerk (De Kloe 2007; Erwich 2008; Nel 2009; Platt 2010; Schwarz 2000; Schwarz 1996:13, 18; Simonian 1999).

Schwarz se benadering behels agt kenmerke of terreine of waarhede wat as Skrifgetroue beginsels vir organiese groei by kerke geïdentifiseer is. Organiese groei word deur die werking van die Gees bewerkstellig wanneer gesonde toestande (dit wat die mens bedink en daarstel) die potensiaal (dit wat God binne die terreine daargestel het) laat gedy (Schwarz \& Schalk 1998:1-8). Hierdie beginsels kan kerkmense gebruik om te midde van ongesonde toestande te kom tot selfondersoek, bekering en verandering.

Aangesien die navorser met die aanname werk dat daar wel 'n wanbalans in die ekklesiologie van die GKSA ter sprake kan wees en dat die tradisionele stroom wel moontlik vanuit die institusionalistiese denkparadigma leef, word die statiese of organisatoriese kenmerke as beginpunt in die steekproef geneem om sodoende vas te stel in watter mate die statiese 
pool as blokkasie (I-denkwyse) teenwoordig is. Die mate waarin die dinamiese of organiese kant ontbreek, word terselfdertyd ook waargeneem. Die agt kenmerke, naamlik spiritualiteit (godsdienstigheid), bediening (bestaande uit kerugma, koinonia, leitourgia en diakonia), ${ }^{3}$ aanbidding (eredienste), kleingroepe, evangelisasie, strukture, leierskap en verhoudings, vertoon binne gesonde toestande albei pole, naamlik 'n dinamiese en 'n statiese kant.

\section{Teikengroep}

Die steekproef het die funksionering van die verskillende kenmerke ondersoek soos dit tans deur'n gedeelte van sekere krimpende Afrikaanssprekende, Westersgeoriënteerde GKSA-gemeentes in Gauteng en Limpopo bedink en geleef word (Van Helden 2010:263-352). Die twee provinsies is as verteenwoordigende uiterstes in Suid-Afrika geneem: Gauteng het die digste bevolking, vertoon 'n sterk stedelike karakter en word as Suid-Afrika se 'ekonomiese kragsentrale' (Dugeot 2008) bestempel, terwyl Limpopo 'n sterk plattelandse en landboukarakter toon en as die armste in die land beskou word (Schwabe 2004).

\section{Interpretasie van die steekproef}

Dit is belangrik om bewus te wees dat die agt kenmerke onderling heg vervleg is en nie in die praktyk maklik geskei word nie. Ter wille van die ondersoek, word die elemente wel van mekaar geskei. Interpretasie van die vraelyste het volgens die interpretasieskaal geskied wat in Tabel 1 weergegee word.

\section{Samevatting van die belangrikste bevindings \\ Spiritualiteit}

Binne die gereformeerde spiritualiteit is omgang met die Woord die uitgangspunt (B 100.00\%). Dit verleen sekerheid van geloof (B 92.50\%) wat'n soeke na die sigbare krag van die Heilige Gees veronderstel (B 74.36\%). Die oortuiging bestaan verder dat namate die tydsgees verander, veranderings ook in die kerkpraktyk ter sprake is (B 64.56\%) (vgl. die teendeel wat by Bediening hier onder ter sprake is). Die veronderstelde veranderings het die gevestigde kerktaal egter nog nie geraak nie, aangesien die term spiritualiteit nog nie binne die kerkverband as kerktaal funksioneer nie (O 76.25\%). Verder is aangetoon dat emosie as relatiewe saak gereken word $(\mathrm{O}$ $60.76 \%$ ), in die mate dat godsdiensbelewing en ervaring as verstandelike ofrasionele aktiwiteite gereken word.

\section{Bediening}

Binne die GKSA word die dienste of ampte grootliks deur die ouderlinge en die diakens verrig (B 88.61\%), alhoewel hulle

\footnotetext{
3.Begrippe waarna hier verwys word, is: Kerugma (verkondiging wat marturia [getuienis] en didache [lering] insluit), koinonia [geloofsgemeenskap en sorg], leitourgia [liturgie, lof, dank aanbidding], diakonia [liefdesdiens] (Lotter 2005:488; Van der Merwe 2009:39-40), paraklese [versoening, vermaning en vertroosting]. Ander terme wat met paraklese verbind word, is: versoek, aandring, opwek aanspoor, aanraai, vra, betuig, aanmoedig, bemoedig, opbeur, versterk, bevestig, teregwys, weerle, bestraf, vermaan, troos, smeek, aandring, bid, dringend vra, aanroep, uitnooi, waarsku, beroep doen op en aanraai. Met hierdie terme moedig die Gees die mens aan om die vryheid wat God gee daadwerklik uit te leef (vgl. ook Green 2004:52; Williams 2005:569).
}

TABEL 1: Sleutel om die vraelys te interpreteer.

\begin{tabular}{ll}
\hline Persentasie & Die betrokke saak onder bespreking \\
\hline $0-49$ & word as onbeduidend beskou \\
$50-59$ & word as relatief gesien \\
$60-69$ & is wel ter sprake \\
$70-79$ & word erken as 'n bestaande realiteit \\
$80-89$ & manifesteer grootliks \\
$90-99$ & manifesteer uitermate baie \\
100 & manifesteer as uitgangspunt \\
\hline
\end{tabular}

Die persentasies word bevestigend (B), ontkennend ( $\mathrm{O}$ ) en as soms ( $\mathrm{S}$ ) aangetoon.

effektiwiteit en die mate van toewyding onder verdenking staan (B 46.15\%; S 36.15\%). Gevestigde gewoontes word in die bediening gehandhaaf (B 75.00\%), met die gevolg dat vernuwende denke rakende dienste of ampte nie manifesteer nie (B 30.77\%; S 43.59\%), omdat dit as 'n relatiewe saak beskou word. Dit geskied téén die veronderstelde oortuiging in dat namate die tydsgees verander, verandering in die kerkpraktyk ter sprake is (vgl. die teendeel by Spiritualiteit hier bo). Ontdekking van gawes word as 'n relatiewe saak beskou (B 59.49\%) (vgl. Leierskap hier onder). Hierteenoor is die amp van die gelowige as aktiewe diens (B 65.00\%) wel ter sprake en die amp geniet binne die individu se persoonlike uitlewing hoë prioriteit (B $81.26 \%$ ). Die diskrepansie tussen die formele diens van die ouderlinge en die diakens en die informele diens van die gelowige, toon die rasionele verwerking en uitlewing van die (onbewuste) wanbalans rakende hierdie dienste. Die bedieningstruktuur fokus uitermate sterk op geestelike opbou as kollektiewe saak (B 92.50\%), terwyl die fokus op uitbou (missionêr) as 'n relatiewe saak beskou word (B 57.50\%) (vgl. Kleingroepe en Evangelisasie wat hier onder bespreek word).

\section{Aanbidding en eredienste}

Rakende die GKSA-predikant as prediker, word gestel dat hy as sentrale persoon binne die erediens funksioneer (B 75.32\%). Dit veronderstel verder dat uitermate baie moeite met preekvoorbereiding gedoen word (B 96.20\%), dat die prediking grootliks relevant is (B $80.77 \%$ ) en dat die gevestigde tradisionele gebruike en vaste liturgie grootliks sekerheid aan die gemeente verleen (B 81.01\%). Ten spyte van die opbou na binne, vind getallegroei egter nie plaas nie en beleef die lidmaat tydens eredienste nie dieselfde mate van entoesiasme (B 59.74\%) as die predikant nie (B 93.67\%). Verder heers ook die oortuigde veronderstelling dat predikante vir die veranderende tydsomstandighede (B 71.79\%) toegerus is. Voortdurende aanpassing deur onder andere die gebruikmaking van veranderende gebruikstaal binne die kerkpraktyk, word as 'n relatiewe saak gesien (B 55.64\%) (vgl. Spiritualiteit wat hier bo bespreek is).

Vreemdelinge se waarneming van eredienste is dat die Woord absoluut sentraal staan (B 100.00\%) (vgl. Spiritualiteit bo) en dat tradisie en stigtelikheid uitermate baie manifesteer (B 93.67\%). Die oortuigde veronderstelling is dat geestelike inspirasie grootliks uit die erediens geput word (B 87.18\%) in weerwil van die rasionele wat oorheers (vgl. Spiritualiteit en Bediening hierbo). 


\section{Kleingroepe}

Groepe en kleingroepe word as sinoniem gereken. Groepe vorm hoofsaaklik rondom Bybelstudie (B 92.21\%), die sustersaktiwiteite en ander ouderdomsgroepe (tieners B $68.42 \%$; studente en werkendes - B $64.47 \%$; en seniors B 77.03\%). Die groepe funksioneer hoofsaaklik ter wille van opbou. Die oortuiging bestaan dat groepe binne die gemeente 'n veilige en intieme omgewing bied waar opbou en bemagtiging van lidmate plaasvind (B 61.33\%). Die afwesigheid van kleingroepe asook die tradisionele groepe binne klein gemeentes, is nie 'n ongewone verskynsel nie.

Die term kleingroepe, asook die betekenis wat die term aan die begin van die een-en-twintigste eeu verder inhou (holistiese versorging deur mede-eienaarskap vir mekaar te aanvaar, asook die doel om na buite uit te reik), word as relatiewe sake beskou (B 54.43\%) en realiseer bykans nie in die kerkpraktyk nie (vgl. Evangelisasie hierna).

\section{Evangelisasie}

Die oortuigde veronderstelling wat grootliks gehandhaaf word, is dat evangelisasie en sending deur 'n kommissie hanteer word (B 81.08\%). Die term, evangelisasie, is egter bekend. Met hierdie term word bedoel dat kerklos lidmate opgesoek word en dat daar aan hulle fisiese, sosiale en geestelike nood aandag geskenk word (B 71.05\%). Verder is die veronderstelling dat die groot opdrag binne die gemeentes ter sprake is en wel gehoorsaam word (B 64.56\%) (vgl. die Bevindings in die lig van I-denke wat hier onder volg). Die term, dissipelskap, is binne gemeentes ter sprake (B 69.62\%) en maak deel uit van die gereformeerde identiteit (B 68.35\%). Hierdie oortuiging sluit aan by die sienswyse dat, aangesien die Woord sentraal staan (vgl. Spiritualiteit en Aanbidding), die groot opdrag derhalwe ook vanselfsprekend sentraal staan. Die teendeel rakende die groot opdrag toon die ongebalanseerdheid binne die kerkpraktyk duidelik aan, aangesien sending as ' $n$ relatiewe saak gereken word. Hierby aansluitend word gemeen dat sending 'n aktiwiteit is wat ver van die gemeente af verrig word (B 55.84\%).

\section{Strukture}

In bykans elke dorp of voorstad is daar 'n kerkgebou vir elkeen van die onderskeie susterskerke (B 100.00\%). Daar is dus meer kerkgeboue as wat die getallepotensiaal binne 'n dorp of voorstad behels. Volgens die beste wete van die GKSA-lidmaat rakende die krimping van getalle in susterskerklike verband, is aangetoon dat onsekerheid heers ten opsigte van die NG Kerk (56.25\%) en die NH Kerk (72.00\%), terwyl die besef van die krimping van die GKSA wel bestaan (B 76.25\%). Binne die gevestigde denkraamwerk dryf die bewussyn van krimpende getalle nie die kerkverband tot aktiewe aanpassing en verandering nie (vgl. die teendeel by Spiritualiteit en Aanbidding). As anker in die veranderende tye is die fisiese kerkgebou ter sprake (B 68.75\%), asook dat die kerkgebou grootliks as 'n simbool vir waardes en norme beskou word (B 82.28\%). Binne die denkraamwerk van die GKSA-lidmaat funksioneer die kerkgebou wel as 'lanseerplek' vir projekte, maar nie as 'n missionêre dryfveer nie (B 63.29\%) (vgl. Evangelisasie hier bo).
Die skynbare ondenkbaarheid van die verkoop van die fisiese kerkgebou en die gevolglike verlies aan 'n fisiese kerkstruktuur weens krimpende getalle, word as 'n relatiewe saak benader (B 51.90\%). Verandering en aanpassing van strukture om aan die eise van die huidige tydsgewrig te voldoen, word ook as 'n relatiewe saak gesien (O 52.50\%) (vgl. Spiritualiteit en Aanbidding). Binne die bedieningstruktuur word eerder by gevestigde sekerhede gehou, al is dit nie altyd funksioneel nie (B 62.50\%) (vgl. Spiritualiteit en Bediening).

\section{Leierskap}

Die predikant word as die leier beskou, terwyl die veronderstelde leiers in die dienste of ampte nie vanselfsprekend as die leiers gesien word nie (B 37.50\%) (vgl. Bediening hier bo). Die bevinding na aanleiding van die kwalitatiewe ondersoek toon dat vrouelidmate as organisatoriese leiers op die voorgrond tree (vgl. die bespreking by Kleingroepe), asook diegene wat die gawes het om te lei. Die siening is verder dat dit geestelike leiers se taak is om die gemeente geestelik op te bou (B 95.00\%), aan te moedig om 'n sukses van die jaarprogram te maak (B 83.75\%) en om lidmate aan te moedig om hulle gawes te ontdek en te ontwikkel (B 88.75\%) (vgl. Bediening). Die veronderstelling is verder dat toerusting verskaf word met die oog op evangelisasie (B 78.48\%) (vgl. die teendeel by Evangelisasie). Die veronderstelling is ook dat die leierskap op identifisering van probleemareas binne die bediening ingestel is en dat die fokus in 'n mindere mate op die interpretering van die huidige tydsgewrig gerig is (B 52.50\%) (vgl. Spiritualiteit, Bediening en Aanbidding wat bo bespreek is). Verder word gemeen dat die volgende aspekte relatiewe sake vir die leierskap is: die maak van die kerklike 'skoppelmaai's (vgl. Leierskap) (B 59.21\%), die missionêre ingesteldheid (B 58.23\%), asook om as daadwerklike voorlopers met vernuwende perspektiewe op te tree (B 52.50\%).

Die veronderstelling is dat die leiers in die GKSA-gemeentes Woordgesentreerd moet wees (B 77.33\%) (vgl. Spiritualiteit, Aanbidding en Evangelisasie). Hierdie veronderstelling impliseer dat die predikant as leier grootliks bewus is van God se plan met die gemeente (B $80.00 \%$ ) en dat die predikant grootliks met die Heilige Gees vervul is (B 88.46\%) (vgl. Spiritualiteit). Die mening is dat outokratiese optrede wel nie prominent na vore kom nie, maar dat dit tog soms teenwoordig is (O 31.65\%; S 45.57\%). Die veronderstelling is dat die predikant die gemeente moet opbou (B 74.36\%). Verder word gereken dat onbetrokke lidmate bloot deel uitmaak van die gevestigde kerksisteem (B 37.66\%; S 45.57\%). Die mening heers dat die predikant in sy werksprogram deur helpers bygestaan word (B 60.26\%), terwyl dit in die gemeente ter sprake is dat die predikant veronderstel is om op hoogte te wees van alles wat in die gemeente aangaan (B $62.03 \% ; \mathrm{S} 35.44 \%$ ). Die nastreef van 'n missionêre bediening word as 'n onbeduidende saak beskou (B 46.05\%; S 42.11\%) (vgl. Kleingroep en Evangelisasie).

4.Die idee is dat die kerkpraktyk jaar in en jaar uit op dieselfde manier beplan bestuur en deurgevoer moet word, aangesien dit skynbaar ' $n$ ongeskrewe reël in die denkmaatstaf is dat daar nie van gevestigde, tradisionele kerkpraktyk afgewyk moet word nie (vgl. Burger 1999:95-104; Du Toit et al. 2002:27, 245; Olivier moet word nie
2006:80-152). 


\section{Verhoudings}

Verhoudings binne die GKSA-gemeentes getuig dat onderlinge aanvaarding, respek en geduld ter sprake is (B 65.00\%), terwyl onderlinge verdeeldheid binne die gemeentes nie ter sprake is nie (O 61.25\%; S 32.53\%). Die lidmaat se geloofsindividualisme, afsydigheid of ingekeerdheid (O 35.00\%; S 52.50\%), vriendelike kontak voorspruitend uit spontane liefde (B 47.50\%; S 52.50\%), asook kontak oor die kleurgrens heen (B 25.00\%; S 51.00\%), word as relatiewe sake gereken.

\section{Bevindings in die lig van I-denke}

Elke kenmerk wat ondersoek is, word vervolgens in die lig van I-denke bespreek.

\section{Spiritualiteit (godsdienstigheid)}

Spiritualiteit gaan oor die verstaan en vertolking van die teenwoordigheid en aktiwiteit van God in die mens en in die wêreld van vandag (Smit 1995:24). Spiritualiteit is die primêre grondbeginsel van die kerk en die teologie en word grootliks deur die kulturele tydsgees gevorm (Heitink 1999:271-272; Olivier 2006:24-25, 79, 85, 129). Gereformeerde spiritualiteit word tradisioneel as 'n 'diep eksistensiële betrokkenheid' gesien (Du Toit et al. 2002:8-12) wat tot uiting kom deur nederige dankbaarheid en erkenning van God se goedheid. Gereformeerde spiritualiteit is verder op die ononderhandelbare uitgangspunt gebou dat die Woord as gesagsbasis suiwer nagevolg moet word. Hierdie uitgangspunt is die wesenlike van GKSA-godsdienstigheid en word as die gereformeerde kerke se sterk punt gereken. Hierdie uitgangspunt, met die kerkpraktyk wat daaruit voortvloei, verleen diep sekerheid aan gelowiges. Ervaring en belewing kry derhalwe nie dieselfde klem nie.

Wanneer die soeke na sekerheid in diegevestigde kerkpraktyk gevind word, is die gevaar dat daar nie voldoende onderskeid tussen die organisasie van die kerkpraktyk en die kerk as organisme gemaak word nie. Organisasie en organisme word dan as sinoniem verstaan. Die gevolg is dat die fokus grootliks op die statiese kenmerk (organisasie) val. Dogma, rasionalisme en formalisme is gevolglik op ongebalanseerde wyse teenwoordig. Die dinamiese kant van godsdienstigheid, wat evangelievreugde, emosie, belewing, intuïsie, entoesiasme, passie en 'n getuigende lewende verhouding insluit (Olivier 2006:141; Tickle 2008:123), is ongebalanseerd afwesig.

'n Gesonde spiritualiteit vertoon die dinamiese en ook statiese kante van 'n gebalanseerde eenheid. Die dinamiese kant bewerkstellig die statiese kant, terwyl die statiese kant op sy beurt die dinamiese kant bevorder. Hierdie twee-eenheid is interaktief ter wille van gesonde spiritualiteit. Slegs wanneer spiritualiteit passievol, gesond en gebalanseerd funksioneer, kan opbou en uitbou volgens die groot opdrag plaasvind, en kan krimping van getalle op organiese wyse mettertyd teëgewerk word.

\section{Bediening}

Bediening behels die vier bedieningsvelde wat deur die ampte funksioneer. Indien die I-denkparadigma oorheers (soos dit uit die steekproef onder die betrokke gedeeltes blyk), funksioneer dienste of ampte oneffektief. Dit manifesteer weens eng, verskraalde en geblokkeerde denke ten opsigte van lidmate se gawes en die onderlinge bediening daarvan binne die gemeente. Gevestigde bedieningspatrone bied min ruimte vir vernuwing, bemagtiging en bekering terug na bybelse voorskrifte vir 'n gesonde bediening. Binne 'n ongebalanseerde bedieningsmodel manifesteer opbou en uitbou, soos vervat in die groot opdrag (vgl. Schalekamp 2005b:23-28; Venter 2006:49), nie as 'n eenheidsisteem nie. Slegs wanneer die bedieningsbenadering bemagtigend is en gesond en gebalanseerd funksioneer, kan opbou en uitbou organies volgens die groot opdrag begin funksioneer waardeur krimping op natuurlike wyse mettertyd teëgewerk kan word.

\section{Aanbidding of eredienste}

As gevolg van die oorheersende I-denkparadigma van die betrokke gemeentes wat in die steekproef ter sprake is, manifesteer die wanbalans sterk binne hierdie ekklesiologiese kenmerk. Die wanbalans word veral weerspieël rondom die aanname rakende die teenwoordigheid van God as 'n vanselfsprekendheid, rondom die rol van die predikant en predikante-opleiding en rondom blokkasies of belemmerings tydens die erediens.

Binne die gevestigde tradisie van die kerke wat in die steekproef ter sprake kom, is die Woord met reg die fokuspunt tydens tye van aanbidding. Die liturgie en erediensgebruike aan die hand van gevestigde kerktaal, word hoofsaaklik deur die predikant deurgevoer (vgl. Du Toit et al. 2002:244) en verskaf ' $n$ gevoel van sekerheid by die lidmate. Binne die I-paradigma word die predikant, met sy besondere persoonlikheid binne die amp, hoog geag. Dit lei gereeld tot die verhoging van die predikant tot superleiersfiguur (Schwarz 1999:21; Williams 2005:571). Dit word as 'n gegewe aanvaar dat die predikant toegerus is om die veranderende tydsgewrig te kan verwerk en die predikant se oordeel word derhalwe blindelings nagevolg. Die predikant is ook 'n produk van die I-denkparadigma, aangesien opleiding binne die gevestigde denkwyse plaasgevind het. Stemme wat opgaan ter wille van heropleiding van predikante, 'n kurrikulum met die oog op 'n missionêre bedieningsaanpak en 'n meer holistiese en gebalanseerde aanpak tussen die akademie en die praktyk, benadruk die stand van teologiese opleiding (Burger 1999:147-148, 193; Buys 2011; Du Toit 2000:173-174; Du Toit et al. 2002; Fraker \& Spears 1996:33, 169-198; Kirkpatrick 2011; Nel 2009:75-76; Niemandt 2007:40; Oliver 2007; Williams 2005:563-571). Die erediens word ook op hierdie institusionele wyse ingerig en vertoon ongebalanseerdheid deur sterk tekens van formalisme. Deurdat by die gevestigde praktyke gehou word, word die gevoel van sekerheid by lidmate versterk. Goedkeuring van ongebalanseerdhede bevestig die institusionalisme wat in die erediens heers. 
Die fokus op die predikant as aktiewe en enigste erediensbestuurder binne die gevestigde liturgiese patroon, tesame met die gerusgestelde toehoorders, wys dat die gemeentes wat by die steekproef betrokke was, tekens van stagnering, ingekeerdheid en gearriveerdheid vertoon. Die oormaat gearriveerdheid en gebrek aan inspirasie bevestig die wanbalans, aangesien die erediens nie na buite oorvloei en ander mense inspireer om hulle tot die gemeente te voeg nie. Die oormaat institusionalisme wat sprekend is van die oordrewe fokus op die geykte denke rondom die erediens (opbou) en die oordrewe gebrek aan missionêre groei (uitbou), beklemtoon die ekklesiologiese wanbalans binne die aanbidding. Slegs wanneer aanbidding inspirerend is en gesond en gebalanseerd funksioneer, kan opbou en uitbou organies volgens die groot opdrag begin funksioneer. Hierdeur kan krimping op 'n natuurlike wyse mettertyd teëgewerk word.

\section{Kleingroepe}

Kwalitatiewe en kwantitatiewe groei word by die gemeentes wat by die steekproef betrokke was, belemmer of geblokkeer deur die wanbalans in die afwesigheid, die daarstel en die deurvoer van die kenmerk. Groepe wat binne die I-paradigma funksioneer, fokus uiteraard, en met reg, op Bybelstudie-met die Woord as bepalend vir die groep se byeenkoms. Hierdie doelstelling as statiese gegewe, verleen sekerheid aan die groep. Verdere doelstellings van gebalanseerde kleingroepe, soos die bereiking van individuele lidmate, die ontdekking van gawes, die holistiese versorging van lidmate en 'n gesamentlike uitreik na buite, manifesteer nie, hoofsaaklik weens die gebrek aan gebalanseerde leierskap (vgl. Brouwer et al. 2007:154; Burger 1999:198; Olivier 2006:140; Strong 2007:128; Wijnbeek 2007:43). Die term kleingroep, word as sinoniem vir die tradisionele groep gebruik, naamlik opbou rondom die Woord waar twee of meer lidmate byeenkom. Die oormaat fokus op die opbou van kennis (rasionalisme) binne die tradisionele praktyk, die tekort aan aandag waar fisiese, sosiale en persoonlike behoeftes binne die groep voorkom (holistiese benadering), asook die afwesigheid van uitbou of uitreik na buite, beklemtoon die ekklesiologiese wanbalans. Slegs wanneer kleingroepe holisties benader word en gesond en gebalanseerd funksioneer, kan opbou en uitbou organies volgens die groot opdrag begin funksioneer, waardeur krimping op natuurlike wyse mettertyd teëgewerk word.

\section{Evangelisasie}

Wanbalans rakende evangelisasie manifesteer op krisisvlak binne die ekklesiologie van die betrokke gemeentes wat by die steekproef betrokke was, deurdat begrip oor wat die groot opdrag behels, grootliks ontbreek. Dit lei selfs tot die totale afwesigheid van evangelisasie-aktiwiteite.

Die Woord as basis, met evangelisasie as begrip wat hieruit voortspruit, word binne die tradisionele denkraamwerk aan die hand van die kerkstruktuur, deur middel van 'n kommissie, tot aktiwiteit beplan. Die wanbalans in die manifestering van evangelisasie, sending en dissipelskap toon dat die kerkpraktyk vanuit 'n tradisie optree, wat nie van balans in die ekklesiologiese eenheidsisteem getuig nie. Die groot opdrag met evangelisasie, dissipelskap, die hantering van fisiese en sosiale behoeftes, asook sending, word volgens I-denke ook as vanselfsprekend geag. Die oormaat fokus op opbou, die gebrek aan fokus op uitbou en die direkte bevel van die groot opdrag, beklemtoon die wanbalans en dominante realisering van institusionalisme binne die tradisionele ekklesiologie (Anon. 2007:41; Oliver 2007:23-40; Van Rooy 2007a:39-41; Wijnbeek 2007:43-45). Slegs wanneer evangelisasie behoeftegeorienteerd is en gesond en gebalanseerd funksioneer, kan opbou en uitbou organies volgens die groot opdrag begin funksioneer en kan krimping op 'n natuurlike wyse mettertyd teëgewerk word.

\section{Strukture}

Wanneer die kerkpraktyk se struktuur ingerig word, kan dit in eensydigheid verval, aangesien strukture mensewerk is as gevolg van menslike denke. Ongebalanseerdhede en blokkasies weens fisiese en nie-fisiese kerklike strukture, is derhalwe ook deur I-denkendes daargestel. Die fisiese kerkgebou as struktuur, voldoen aan die mens se behoefte en soeke na vastigheid en sekerheid. Die kerkgebou dien ook as simbool van 'n waardesisteem en bied 'n anker vir emosionele verbintenis. Nie-fisiese strukture bied ook sekerheid, aangesien die gang van jarelange tradisies as suksesvol beleef word, al bestaan blokkasies en oneffektiewe funksionering van die betrokke strukture.

Die krag van institusionalisme aan die hand van strukture en sekerhede daarrondom, soos dit blyk uit die resultate van die steekproef wat onder die betrokke gemeentes gedoen is, belemmer op gereelde basis denkwysigings, denkaanpassings en denkveranderings wat moontlik na vore kan kom. Die keuse tot verbondenheid aan gevestigde sekerhede werk derhalwe die moontlikheid van verdere vertraging van buigbaarheid en aanpassing in die hand. Sekerhede, gebou rondom strukture, oorheers oorwegend ten koste van funksionaliteit binne die bediening. Dit gebeur omdat strukture binne die I-denkraamwerk maklik tot beginsels verhef word (vgl. Du Toit et al. 2002:27, 47; Niemandt 2007:38-41; Olivier 2006:140; Van der Spuy 1998:119; Warren 2005:301, 313, 325).

Die hoë frekwensie van skynbaar onwysigbare, tradisionele gemeentestrukture, bevestig die bestaan van die I-denkraamwerk binne die gemeentes wat by die steekproef betrokke was. Die denkwyse toon dat die fokus op opbou val, met ingekeerdheid en blokkasies wat ten koste van uitbou manifesteer. Onregmatige gewig wat aan fisiese en nie-fisiese strukture verleen word, lei tot leë kerke en geykte strukture. Dit toon sterk tekens van onaanpasbaarheid en oneffektiwiteit rakende strukture. Slegs wanneer strukture funksioneel is en gesond en gebalanseerd funksioneer, kan opbou en uitbou organies volgens die groot opdrag begin funksioneer, waardeur krimping op natuurlike wyse mettertyd teëgewerk kan word. 


\section{Leierskap}

Leierskap openbaar belemmerings, waarvan gebrek aan Geesvervuldheid in die resultate van die steekproef, uitstaan. Dit kan tot 'n wanbalans op die gebied van bemagtiging lei, veral ten opsigte van die beoefening van gawes. By die I-paradigma is die uitgangspunt dat die Woord sentraal staan en onkreukbaar deur die leierskorps nagevolg word. Geestelike opbou deur die Woord is derhalwe die hooftaak van die leierskorps. Dat God se plan in samewerking met die gemeente deurgevoer word, is 'n verdere vanselfsprekendheid. Die denkraamwerk hou in dat die predikant per se vervul is met die Heilige Gees, per se die gemeente bemagtig en per se missionêr gerig is. Die GKSA se geestelike leiers of predikante kan op grond hiervan as 'beyond question' (vgl. Schwarz 1999:7) gereken word. In werklikheid manifesteer ' $n$ missionêre bediening glad nie. Institusionele blindheid blokkeer kennisname van die ware toedrag van sake. Die verskynsel van die superleiersfiguur, omring deur ontmagtigdes (binne en buite die ampte) (vgl. Roxburgh 1997:62-64; Van Rooy 2007b:31-32) manifesteer sterk in hierdie paradigma en skep 'n platform vir formalistiese en outokratiese optrede.

Sodanige optrede en denkwyse lei tot selfgerigtheid, 'wankelmoedige leierskap' (Warren 2005:xvi) en stagnasie, deurdat die werking van die Gees bemoeilik en soms selfs geblus word. Die gevolg is dat die predikant as leier (in homself) faal, hoofsaaklik omdat die opleiding slegs rondom prediking gesentreer het en verdere bemagtiging rakende die totaliteit van ekklesiologiese eise, tekort skiet. Ter wille van oorlewing van die beroep, word dan agter die I-paradigma geskuil, en daardeur word die predikant se optrede asook die voortgang van die teologiese 'skoppelmaai' geregverdig (vgl. Burger 1999:95-104; Du Toit et al. 2002:27, 245; Olivier 2006:80-152). Die I-paradigma, waarvolgens teologiese opleiding ontvang is, word op institusionalistiese wyse in die kerkpraktyk voortgesit (vgl. Aanbidding). Slegs wanneer leierskap bemagtigend is en gesond en gebalanseerd funksioneer, kan opbou en uitbou organies volgens die groot opdrag begin funksioneer en kan krimping op natuurlike wyse mettertyd teëgewerk word.

\section{Verhoudings}

Soos dit uit die resultate van die steekproef blyk, manifesteer daar binne die susterskerke 'n wanbalans ten opsigte van verhoudings, aangesien die veronderstelde liefdesbeginsel, gereformeerde identiteit en Christelike geloofwaardigheid nie op'n gesonde basis realiseer nie. Gesonde en doelbewuste liefdesdade getuig van verhoudings voortspruitend uit horisontale liefde (tot die mens), in balans met vertikale liefdesdade (tot God).

Liefdevolle verhoudings manifesteer selde waar institusionalisme in die vorm van wettisisme, kerkisme en formalisme of geslotenheid hoogty vier. Identiteit en verhoudings gaan hand aan hand deurdat gehoorsaamheid aan die groot opdrag die stukrag vorm. Indien 'n eensydige verstaan van die groot opdrag manifesteer, is daar 'n wanbalans in die opbou en uitbou.
Opbou met 'n lae kwosiënt doelbewuste vrugbetoon ten koste van uitbou, toon die warm-kop-koue-hartgesindheid (vgl. Wijnbeek 2006:34). Die wanbalans dui op 'n gebrek aan ware en egte verhoudings en is kenmerkend van nie-groeiende kerke. Onsekerheid in verhoudings dui op ongebalanseerdheid en 'n tekort aan liefdesdade. Uitbou deur doelgerigte verhoudings ontbreek grootliks, aangesien I-denke binne die Afrikaanssprekende Westersgeoriënteerde kerke domineer (Hendriks 1999). Deur die gevestigde tradisionele ekklesiologie binne 'n I-paradigma, neig opregte, liefdevolle verhoudings om nie kragdadig te manifesteer nie en onderlinge verdeeldheid deur afsydigheid kan ervaar word. Liefdevolle verhoudings manifesteer gewoonlik nie waar daar ' $n$ gebrek is aan evangelisasie en kleingroepbediening of ' $n$ gebrek aan identiteit bestaan nie. Die oormaat institusionalisme en die tekort aan 'n hoë kwosiënt liefdevolle verhoudings beklemtoon die ekklesiologiese wanbalans (vgl. Schwarz 1999:134, 145). Slegs wanneer verhoudings liefdevol is en gesond en gebalanseerd funksioneer, kan opbou en uitbou organies volgens die groot opdrag begin funksioneer, waardeur krimping op natuurlike wyse mettertyd teëgewerk kan word.

\section{Samevattende konklusies rakende die bevindings}

Die gemeentes wat by die steekproef betrokke was en tot 'n groot mate verteenwoordigend is van die huidige oorwegend institusionalistiese GKSA-kerkpraktyk, getuig van die vaste oortuiging dat die Woord sentraal staan en dat suiwer navolging daarvan plaasvind. Hierdie oortuiging bied sekerheid en tevredenheid met die status quo. Terselfdertyd word die kerkpraktyk oorheers deur rasionalisme, gevestigde ordelikheid en ingekeerdheid. In die toetsresultate is die missie van die kerk op aarde (missionêre kerkpraktyk of groot opdrag) opsigtelik afwesig. Dit blyk dat sekere oortuigings wat deur jarelange tradisie gevestig is, blindelings as 'suiwer' Skrifnavolging beskou word. Dit hou waarskynlik ten nouste verband met die feit dat werklike en eerlike oningeligtheid, onkunde, onwetendheid en selfs denkverwarring bestaan rakende die implikasies van die groot opdrag, asook die eise ten opsigte die veranderende tydsgewrig waarin tans geleef word.

Uit hierdie steekproef is dit duidelik dat die I-denkwyse in die bepaalde gereformeerde stroom wat ondersoek is, springlewendig is - die statiese kenmerke is só prominent dat die dinamiese kenmerke nie manifesteer nie. Die eenheidsisteem (opbou of dissipelmaak-bevel binne die gemeente en die uitbou na buite deur die uitbou of gaanbevel) funksioneer nie binne die betrokke gemeentes nie.

Die besef hieromtrent kan in terme van ' $n$ realiteitskok beskryf word: in eenvoudige taal beteken dit dat standpunte wat in die tradisioneel-gereformeerde kerke gevind word - kerke waarin stoer en eerlik geglo word dat die Woord 'suiwer' nagevolg word - in werklikheid op selfbedrog neerkom. Dit kan daarop neerkom dat die groot opdrag, as laaste opdrag van die tydperk voor die wederkoms, nie volgens sy gewig verstaan of gehoorsaam word nie. Hierdie realiteitskok 
behoort aanleiding te gee tot diepgaande selfondersoek. Hierdie soort selfondersoek kan tot reformerende denke en veranderende dade lei en kan tradisionele kerke weer terug rig tot werklike suiwer verbondsnavolging van die Woord (Burger 1995:13, 23-26; De Wet 2000:7; Hendriks 1996:143, 1999:19).

Die eenheidswerking binne die verbondsverhouding is volgens Van Ruler, aangehaal deur Park (2005:20), 'onnaspeurlijke werk'. Die eenheidswerking bly dus 'n sleutel vir die gelowige mens in sy roeping om 'n gebalanseerde, gesonde kerkpraktyk daar te stel (Bosch 1991:40; Schalekamp 2005b:23-28; Schwarz 1999:6-18; Vosloo \& Janse van Rensburg 1999:1187).

\section{Christosentriese denkparadigma}

\section{Balanserende paradigma}

Die Christosentriese denkparadigma, ook bekend as die bipolêre teologiese denkparadigma, is die sentrale en balanserende paradigma tussen die I- en S-paradigmas, wat op Christus as balansgewende middelpunt fokus (De Kock 2003:17, 85-110, 166; Du Toit et al. 2002:49; Dreyer 2009:8-9; Heitink et al. 2000:53-71; Niemandt 2007:62-71; Schwarz 1996, 1999:6-18, 71, 218-220; Tickle 2008:27-28). Die bipolêre denkparadigma toon uiteraard ook die twee inherente pole, naamlik die statiese en die dinamiese pole (vgl. ook Rom 12:3-8, 1 Kor 3:9-10, 12:12-31, 1 Pet 2:4-8, Ef 2:19-22). By elkeen van die agt kenmerke is dus 'n statiese sowel as dinamiese pool teenwoordig (Schwarz 1999:20-21). Indien slegs op een van die pole gekonsentreer word, ontstaan 'n wanbalans. Die wanbalans bemoeilik organiese (natuurlike en gesonde) ontwikkeling en werk op die lang duur kerkkrimping in die hand. Die statiese pool verwys na die menslike denke en dade, veral rakende die organisatoriese kant van die kenmerk, terwyl die dinamiese pool na die menslike denke en dade, veral ten opsigte van die organiese kant verwys.

Plasing van die bipolêre teologiese denkparadigma is volgens 'n weegskaalbeeld tussen die twee uiterste denkparadigmas: tussen die S-denkparadigma aan die een kant en die I-denkparadigma aan die ander kant. Die charismatiese stroom vertoon ongebalanseerdheid deur oorwegend S-paradigmakenmerke, terwyl die tradisionele stroom oorwegend kenmerke van die I-paradigma vertoon. Hierdie uiteenlopende twee pole is 'n sterk aanduiding dat daar 'n wanbalans binne albei strome bestaan. Om die hedendaagse I-paradigmadenke binne die problematiese kerkpraktyk van die susterskerke tot die gebalanseerde bybelse bipolêre denkparadigma te rig, is ' $\mathrm{n}$ denkverandering as opdrag ter sprake.

\section{Denkverandering}

'n Bybelse begronding vir die opdrag tot verandering is algemeen in die Skrif en spesifiek in Romeine 12:1-2 en Johannes 3:1-8 (Burger 1999:302). Die Skrif, asook sosioloë soos Lave en Wenger (1991:34), stel onomwonde dat die mens oor die vermoë beskik om verandering van denke daar te stel: 'Of all the creatures on earth ... only human beings can change their pattern'.

In Christus lê die locus classicus, die kern van alles wat heilsaam, nuttig en funksioneel is. Christus as balanserende middelpunt tussen die I-paradigma en S-paradigma, rig die gelowige tot kruisgesentreerde denke (bipolêre denke) (Du Toit et al. 2002:49; Heitink et al. 2000:53-71). Deur 'n Christusgesentreerde verbondslewe word Jesus as Hoof en as die balanserende anker in die kerk erken. Christusgesentreerdheid sonder enige plusse toon reformerende denke (Botha 2006:47). By Christus, as die Woord en die Lewe, is die oplossing van ongebalanseerdheid: die Woord en die werklikheid word binne die eenheidswerking van statiese en dinamiese aspekte radikaal en funksioneel by mekaar gebring. Hierdie veranderde fokus deurtrek die menslike denke, wat op sy beurt weer die hele bedieningsveld deursuur.

\section{Verandering as praksis van God}

God Drie-enig verkeer in sy ewige raad kommunikatief. Hieruit voortspruitend het die stuurproses in aanvang geneem: die missionêre Vader, die Seun as die Woord (as vleesgeworde kommunikasie), en die Heilige Gees (as werkende kommunikasie) stuur op sy beurt weer die mens aan die hand van die groot opdrag. Deur menslike pastorale denke en handelinge geskied menslike kommunikasie (kerugma, marturia, didache, leitourgia, koinonia, paraklese en diakonia) soos geïnisieer en deur God Drie-enig bedoel is. Op hierdie wyse is die gelowige mens tot seën van ander en word daar voldoen aan die grondwet van die kerk wat verbondsmatig vanuit Genesis 12:2 spreek: '... jy moet tot'n seën wees'.

Ten diepste is die kommunikatiewe handeling die praksis van God self (Bosch 1991:378-381, 389-393; De Kock 2003:77; Heitink et al. 2000:53-71; Niemandt 2007:147, 154). Deur die Christusgesentreerde denkparadigma word korrekte Godskennis (denke) bekom en weet die verbondsgelowige dat God deur Christus met hierdie menslike opdrag tot kommunikasie sal volhou totdat elke uitverkorene tot geloof gekom het dit was immers die doel van God se kommunikatiewe besluit.

\section{Verandering as praksis van die mens}

Slegs in die lig van 'n radikale menslike denkverandering en radikale gehoorsaamheid aan Jesus Christus, sal 'n veranderende gereformeerde kerkpraktyk in die eenen-twintigste eeu 'n werklikheid kan word (vgl. ook Janse van Rensburg 2000:94). Verwerkliking van die denkverandering behels vier allesomvattende sake wat te alle tye ter sprake is en die veranderingsproses dring, rig, omvou en deurweef. Wat eerstens ter sprake is, is 'n hartsgedrewe Christus-gesentreerdheid. Tweedens rig Christus se groot opdrag (missio Dei) die mens tot kragtige roepingsbesef (gehoorsaam in die opbou en uitbou as eenheidsisteem). Die roepingsgedrewenheid omvou derdens 
die mens tot verstandige en doelgerigte bevordering van die biotiese (organiese) beginsels. Vierdens deurweef afhanklike en oorgegewe gebedsgesindheid die voorafgaande gesentreerdheid, gedrewenheid en uitgangspunt. Deur die vier allesomvattende aspekte (voortspruitend uit gehoorsaamheid aan die groot gebod - hart, krag, verstand en siel), kan vas en seker in die Skrifbeloftes geglo word. Hierdie beloftes word deur die Gees op natuurlike wyse deur groei daargestel. Organiese groei staan egter in radikale kontras met Gilbert (2004) se beeld van 'n 'slow death' -'n beeld wat 'n mens tot 'n groot mate deur die ongebalanseerdhede in die huidige kerkpraktyk herken.

\section{Natuurlike groeimoontlikhede}

Blokkasies en ongebalanseerdhede wat weens die I-paradigma skynbaar ook in die ander susterskerke teenwoordig is, behoort bewustelik deur die verbonds- 'bestuurders' (Tit 1:3 en 5), aan die hand van die bipolêre Skrifparadigma, geïdentifiseer en verwyder te word. Die doel met hierdie doelbewuste denke en beplanning (verstandsaksie) is om die kerkpraktyk te suiwer, Daarna moet die teendeel met volle krag, met die hele hart, siel en verstand (groot gebod) sodanig bedink word dat die moontlikheid tot natuurlike groeimoontlikhede daargestel kan word. 'n Kerkpraktyk moet vanuit die vier allesomvattende aspekte bedink, beplan en geleef word volgens die voorskrifte van die groot opdrag (dinamies en staties) op 'n gebalanseerde wyse binne elkeen van die agt kenmerke (op voorbereide en doelbewuste wyse). 'n Mens kan glo en verwag dat die Gees sodanige gesonde omstandighede tot groei van die koninkryk wil gebruik.

Ontwikkeling en groei vind derhalwe plaas waar geestelike opbou en uitbou organies voorkom (dinamies) en waar organisatoriese funksionaliteit sigbaar is (staties). Uitverkorenes word toegevoeg en deur die dissipelmaakproses opgebou (vgl. Brouwer et al. 2007:106-108). Gemeentes wat binne die bipolêre, biotiese Christusgesentreerde Skrifparadigma funksioneer, ervaar die natuurlike, organiese eenheidswerking waardeur ontwikkeling plaasvind deur kwalitatiewe (opbou) en kwantitatiewe (uitbou) groei (vgl. Schwarz 1999:216-218; De Klerk \& Van Helden 2011:1-2).

\section{Christus as enigste alternatief}

'n Denkverandering met Christus as die middelpunt dring 'n mens om dringend, ernstig en op volhoubare wyse daarna te streef en te werk om ' $n$ gebalanseerde en balanserende kerkpraktyk daar te stel (Schwarz 1999:23, 40, 212-213, 221-223). Daar is nie 'n alternatief vir die krimpende tradisionele stroom nie - dit is óf hierdie diep, radikale reformasie, óf 'n stadige en gewisse sterwe (Gilbert 2004; Niemandt 2007:11). Deur diep reformasie word die ontoereikende en krimpende kerkprakyk bewustelik aan die hand van Christosentriese beginsels op ware 'suiwer' wyse tot ' $n$ verbeterende Suid-Afrikaanse gereformeerde praktyk getransformeer (vgl. De Kloe 2007).

\section{Slot}

Die problematiese toedrag binne die tradisionele gereformeerde kerke word toegeskryf aan die dominante I-denkwyse wat tot uiting kom in die krimpende kerkpraktyk. Deur jarelange ongebalanseerde en ongesonde denke en dade is die bybelse beginsels wat organiese of natuurlike groei bewerkstellig, aan die begin van die een-en-twintigste eeu nie meer die norm nie. Hierdie ernstige en noodeisende toedrag van I-denke as dominante denkparadigma en dryfveer vir dade in die huidige kerkpraktyk, word ondubbelsinnig deur die steekproef bevestig. 'n Diepgaande denkverandering, terug na die balanserende Christosentriese denkparadigma as korrektief aan die hand van die groot opdrag, bied die enigste hoop in die teenswoordige steeds springlewendige, kwynende tendens binne die susterskerke (Hendriks 1996:142, 1999:19; Tickle 2008:143).

\section{Erkenning Mededingende belange}

Die outeur verklaar dat sy geen finansiële of persoonlike verbintenis het met enige party wat haar nadelig kon beïnvloed in die skryf van hierdie artikel nie.

\section{Literatuurverwysings}

Anon., 2007, 'Teologiese studente doen sendingprakties', Die Kerkblad April, 41.

Bosch, D.J., 1991, Transforming mission - Paradigm shifts in theology of mission, Orbis Books, New York.

Botha, N., 2006, 'Nou ken ons ons ellende beter', Die Kerkblad Mei, 47.

Brouwer, R., De Groot, K., De Roest, H., Sengers, E. \& Stoppels, S. (reds.), 2007, Levend liggaam: Dynamiek van christelijke geloofsgemeenschappen in Nederland, Kok, Kampen.

Burger, C., 1995, Gemeentes in transito - Vernuwingsgeleenthede in 'n oorgangstyd, Lux Verbi, Kaapstad.

Burger, C., 1999, Gemeentes in die kragveld van die Gees oor die unieke identiteit, taak en bediening van die kerk van Christus, Gemeentes en bediening 4, Buvton, Stellenbosch.

Buys, F., 2011, 'Missionêre karakter van die kerk', voordrag gelewer as deel van CRUMA-seminaar, Pretoria, 13 September.

De Klerk, B. \& Van Helden, P., 2011, 'Oorsake van kerkkrimping binne die tradisioneel Afrikaanssprekende gereformeerde kerke in Suid-Afrika', Verbum et Ecclesia 32(1), 1-10. http://dx.doi.org/10.4102/ve.v32i1.477

De Kloe, P., 2007, 'Schwarzprofielen van Evangelische Alliantie naar Paul de Kloe' viewed 10 May 2010, from http://www.ea.nl/v3/index.php?id=Nieuws/ Nieuwsberichten/NCD\%20 naar\%20paul\%20de\%20Kloe

De Kock, H.K., 2003, "n Prakties-teologiese beoordeling van Natural Church Development se agt kwaliteitseienskappe van groeiende kerke, Skripsie voorgelê ter gedeeltelike nakoming van die vereistes vir die graad Magister Theologiae in Pastoraal, $\mathrm{CU}$ vir $\mathrm{CHO}$.

De Wet, F.W., 2000, 'Geloofswaarneming - 'n Teologies-estetiese benadering tot Praktiese Teologie', PhD proefskrif, $\mathrm{CU}$ vir $\mathrm{CHO}$.

Dreyer, W.A., 2009, "n Prakties-teologiese perspektief op kerkwees met besondere verwysing na die Nederduitsch Hervormde Kerk van Afrika', PhD proefskrif, Dept. Teologie, Universiteit van Pretoria.

Du Toit, B., 2000, God? Geloof in 'n postmoderne tyd, CLF-Uitgewers, Bloemfontein. PMCid:91984

Du Toit, F., Hofmeyr, H., Strauss, P. \& Van der Merwe, J., 2002, Moeisame pad na vernuwing: Die NG Kerk se pad van isolasie en die soeke na 'n nuwe relevansie, Barnabas, Bloemfontein.

Dugeot, 2008, 'Dugeot se mieliestronk', viewed 07 Oct. 2008, from http://www. mieliestronk.com/provinsies

Erwich, R., 2008, 'Missionaire gemeenten: wereldwijde identieke plantjes of plaatselijk gegroeide bloemen? De Natuurlijke Gemeente Ontwikkeling van Christian A. Schwarz nader bekeken', besigtig 10 May 2010, vanaf http://www. erwich.eu/admin/file_uploader2/ bestanden/Missionairegemeenten46a0e. pdf

Fraker, A.T. \& Spears, L.C. (eds.), 1996, The private writings of Robert K. Greenleaf Seeker and servant reflections on religious leadership, Jossey-Bass, San Francisco. PMCid:1235372 
Gilbert, D.E., 2004, “Deep change" or "slow death"? A practical road guide for the highway of change: A learning manual for church boards', submitted for the highway of change: A learning manual for church boards', submitted for the Western Theological Seminary in partial fulfilment of the requirements of the degree of Doctor of Ministry, Theological Research Exchange Network, Tren
Databasis.

Green, M., 2004, I believe in the Holy Spirit, Eerdmans, Cambridge.

Heitink, G., 1999, Practical theology: History, Theory, Action domains: Manual for practical theology, transl. R. Bruinsma, Eerdmans, Grand Rapids.

Heitink, G., Pieterse, H.J.C. \& Vos, C.J.A., 2000, "n Poging tot saamdink', Praktiese Teologie in Suid-Afrika 15(2), 53-71.

Hendriks, H.J., 1993, 'Die 1991-bevolkingsensus-tendense en die Afrikaanse kerke', Nederduitse Gereformeerde Teologiese Tydskrif 34(4), 542-551.

Hendriks, H.J., 1996, 'Kerkspieël en die NGK statistiek in die wyer perspektief van die Suid-Afrikaanse bevolkingsensusse 1911-1991', Nederduitse Gereformeerde Teologiese Tydskrif 37(1), 138-145.

Hendriks, H.J., 1999, 'Verwagting vir die nuwe millennium: Gaan Gereformeerde Kerke groei, kwyn of verdwyn?', Woord en Daad 13, 17-19.

Hendriks, H.J., 2003, 'Die toekoms van die kerk, die kerk van die toekoms', besigtig 10 May 2010, vanaf http://academic.sun.ac.za/theology/Profiles/Profile documents/Prof_Jurgens_Hendriks_Intreerede.pdf

Hofmeyr, J.W. \& Pillay, G.J. (ed.), 1994, A history of Christianity in South Africa, vol. 1, HAUM Tertiary, Pretoria.

Janse Van Rensburg, J., 2000, The paradigm shift: An introduction to postmodern thought and its implications for theology, Van Schaik, Pretoria.

Jenkins, P., 2006, The new faces of Christianity - Believing the Bible in die global South, Oxford University Press, Oxford.

Kirkpatrick, J., 2011, Gereformeerde identiteit - droom, werklikheid of oriëntasiepunt, voordrag gelewer as deel van Excelsus se Sesde Lentekonferensie Universiteit van Pretoria, Universiteitsoord, Pretoria, 20-22 September.

Kuyper, A., 1910, Dictaten dogmatiek van Dr A. Kuyper: Locus de Salute, Ecclesia Sacramentis, Locus de ecclesia, Bd. 4, Kok, Kampen.

Lave, J. \& Wenger, E., 1991, 'Legitimate peripheral participation', viewed 17 Dec. 2008, from http://edutech.csun.edu/eduwiki/index.php/Lave_and_Wenger Legitimate_Peripheral_Participation

Lotter, G.A., 2005, 'Die werk van die Heilige Gees volgens 2 Korintiërs en die moontlike pastorale implikasies daarvan', In die Skriflig/In Luce Verbi 39(3), 487-504. http:// dx.doi.org/10.4102/ids.v39i3.399

Malphurs, A., 2004, Planting growing churches for the 21st century, Baker Books, Grand Rapids.

McGrath, A., 2005, The twilight of atheism: The rise and fall of disbelief in the modern world, Rider, London.

Mclaren, B.D., 2006, The secret message of Jesus: uncovering the truth that could change everything, Thoms Nelson, Nashville.

Nel, M., 2009, 'Congregational analysis revisited: Empirical approaches', viewed 10 May 2010, from http://www.scielo.org.za/scielo. php?pid=S025994222009000100033\&script =sci_arttext

Niemandt, N., 2007, Nuwe drome vir nuwe werklikhede, Lux Verbi, Wellington.

Oliver, E., 2007, 'Thoughts on writing Afrikaner church history in the 21st century', Studia Historiae Ecclesiasticae 33(1), 23-40.

Olivier, I.J., 2006, 'The strategic task of the church in creating spaces for spirituality', PhD thesis, Dept. Practical Theology, North-West University.

Park, T., 2005, 'The sacred rhetoric of the Holy spirit: A study of Puritan preaching in a pneumatological perspective', (met een samenvatting in het Nederlands), Proefschrift, Theologische Universiteit.

Platt, A., 2010, 'Natuurlike gemeentegroei, Church Wise', besigtig 10 May 2010, vanaf http://www.churchwise.co.za/about_us.htm

Pretorius, J. \& Lindeque, G., 2009, Mondelinge mededeling aan outeur rakende die bedieningsplan in Linden (GKSA), klankopname, Linden.
Roxburgh, A.J., 1997, The missionary congregation, leadership and liminality, Trinity Press International, Harrisburg.

Saarinen, M.F., 1992, The life cycle of a congregation, The Alban Institute, New York City.

Schalekamp, M.E., 2005a, 'Multikulturele kerkplanting: Ons moet hande vat met ander gelowiges en kerke', Die Kerkblad, Augustus, 24-27.

Schalekamp, M.E., 2005b, 'Missiones Ecclesiae: 'n Missionêre visie en strategie in gemeentebou ten opsigte van multikulturele kerkplanting', PhD proefskrif, Noordwes-Universiteit. PMCid:1884901

Schwabe, C., 2004, 'Fact sheet: Poverty in South Africa, viewed 07 Oct. 2008', from http://www.sarpn.org.za/documents/d0000990/index.php

Schwarz, C.A., 1996, Natural church development: A guide to eight essential qualities of healthy churches, Church Wise, Randhart.

Schwarz, C.A., 1999, Paradigm shift in the church-How natural church development can transform theological thinking, ChurchSmart Resources, Emmelsbüll.

Schwarz, C.A., 2000, Natural church development: A guide to eight essential qualities of healthy churches, S.A. Church Wise, Randhart.

Schwarz, C.A. \& Schalk, C., 1998, Implementation guide to natural church development, Church Wise, Randhart.

Simonian, C., 1999, 'Natural church development: A review - A book by Christian Schwarz', viewed 10 May 2010, from http://www.ourvineyard.org/files/A Review_of_Christian_Schwarz1.htm

Smit, A. (red.), 1995, Nuut gedink oor leierskap in gemeentes: Die begeleiding van 'n Christelike geloofsgemeenskap, Gemeente en bediening 4, Lux Verbi, Kaapstad.

Smit, C.J. \& Vorster, J.M., 2000, 'Die GKSA en sy gereformeerde identiteit: Kan dit behou word in 'n postmoderne gemeenskap?' In die Skriflig/In Luce Verbi 34(4), 515-533. http://dx.doi.org/ 10.4102/ids.v34i4.613

Strong, P., 2007, 'Romans 12:2 as an important paradigm for transformation in a Christian: A practical theological study', PhD thesis, Dept. of Pastoral Studies, North-West University.

Tickle, P., 2008, The great emergence, Baker Books, Michigan.

Van der Merwe, C., 2009, 'SEED-projek basiskursus in bedieningspraktyk aangebied vir die NH kerkleiers, Muldersdrif, 02-05 Maart.

Van der Spuy, D., 1998, Wanneer die Heilige Gees werk, Struik Christelike Boeke, Kaapstad.

Van der Walt, B.J., 2006, 'Die Postmodernisme, 'n verleentheid en 'n geleentheid', Die Kerkblad September, 30-32.

Van Helden, S., 2010, "n Hermeneuties-empiriese strategie rakende die verskynsel van kerkkrimping in tradisioneel Afrikaanse 'susterkerke' in Suid-Afrika - ' $n$ Prakties-teologiese studie', PhD tesis, Departement Praktiese Teologie, NoordwesUniversiteit.

Van Rooy, K., 2007a, 'Kan die Gereformeerde Kerke hoegenaamd nog met die evangelie uitreik?', Die Kerkblad Maart, 39-41.

Van Rooy, K., 2007b, 'Sendingwerk in die toekoms ... Hoe en waarheen?', Die Kerkblad April, 30-32.

Venter, B., 2006, 'Briewe van ons lesers: Waarom verlaat ons lidmate die kerk?', Die Kerkblad Julie, 49.

Vosloo, W. \& Janse Van Rensburg, F. (reds.), 1999, Die Bybellennium: Eenvolumekommentaar, Christelike Uitgewersmaatskappy, Vereeniging.

Warren, R., 2005, Doelgerigte kerk, Struik Christelike Boeke, Kaapstad.

Williams, D.T., 2005, 'The spirit and the academy', Scriptura: International Journal of Bible, Religion and Theology in Southern Africa 89, 563-573.

Wijnbeek, M., 2006, 'Gelowig in 2050?', Die Kerkblad Oktober, 33-34.

Wijnbeek, M., 2007, 'Die kerke loop leeg ... en leër ... en leër', Die Kerkblad Julie, $43-45$. 


\section{Bylaag 1}

'n Vraelys vir gebruik by die ondersoek na die ekklesiologiese oorsake wat moontlik kan bydra tot die verskynsel van kerkkrimping by die susterskerke, maar toegespits is op die GKSA binne die klassisse van Gauteng en Limpopo.

Beste invuller van hierdie vraelys,

Baie dankie dat jy bereid is om tyd af te staan en breinkrag te gee vir hierdie vraelys. Die doel van hierdie vraelys is om die ware stand van huidige gereformeerdheid binne die GKSA, soos dit tans $(2008 / 2009)$ voorkom, aan te toon.

Dit is daarom baie belangrik dat die invul van die vraelys jou absolute eerlike oortuigings weerspieël. Slegs dan kan dit 'n geloofwaardige ondersoek wees en nuttig wees vir identifisering van sterk en swak punte binne die GKSA.

Hierdie vraelys het dus nie 'n memorandum wat aantoon watter vrae is reg of watter is verkeerd nie. Die uitkoms van hierdie ondersoek is bloot om die ware stand van gereformeerdheid in die huidige opset eerlik te wete te kom.

Die vraelyste word anoniem ingevul. Die navorser hanteer dit en sal onder geen omstandighede jou menings met iemand deel nie. Die inligting word deur die NWU-Statistiekdienste verwerk sodat die ware stand van huidige gereformeerdheid in Suid-Afrika, aangetoon kan word.

Lees asseblief die instruksies en beantwoord al die vrae.

\begin{tabular}{|l|l|}
\hline Dui asb. jou geslag aan met ' $n$ kruisie: & \\
\hline Manlik & \\
\hline Vroulik & \\
\hline
\end{tabular}

A. Maak langs elke stelling ' $n$ kruisie in die toepaslike blokkie volgens jou oortuiging

\begin{tabular}{|l|c|c|}
\hline \multicolumn{2}{|l|}{ A1. Die Gereformeerde manier van kerkwees: } & NEE \\
\hline $\begin{array}{l}\text { Die gereformeerde manier van kerkwees gee sekerheid } \\
\text { van geloof }\end{array}$ & JA & NEE \\
\hline $\begin{array}{l}\text { Die gemeente se manier van kerkwees verander omdat } \\
\text { die huidige tydsgees verander }\end{array}$ & JA & NEE \\
\hline Die woord spiritueel is 'n bekende gereformeerde term & JA & \\
\hline
\end{tabular}

\begin{tabular}{|l|c|c|}
\hline A2. Gereformeerdes se manier van kerkwees sluit opsigtelik die volgende in: \\
\hline Emosie & JA & NEE \\
\hline Belewing en ervaring & JA & NEE \\
\hline Intuïsie & JA & NEE \\
\hline Entoesiasme/passie & JA & NEE \\
\hline 'n Soeke na die sigbare krag van die Heilige Gees & JA & NEE \\
\hline Omgang met die Woord & JA & NEE \\
\hline
\end{tabular}

\section{B. Maak langs elke stelling ' $n$ kruisie in die toepaslike blokkie volgens jou oortuiging}

B1. Ouderlinge en diakens se dienste:

Ouderlinge en diakens behartig die dienste in die gereformeerde manier van kerkwees

NEE

\begin{tabular}{|l|c|c|c|}
\hline B2. Effektiwiteit van ouderlinge en diakens: & JA & SOMS & NEE \\
\hline $\begin{array}{l}\text { In hierdie gemeente is ouderlinge } \\
\text { effektief in hul diens }\end{array}$ & JA & SOMS & NEE \\
\hline $\begin{array}{l}\text { In hierdie gemeente is diakens } \\
\text { effektief in hul diens }\end{array}$ &
\end{tabular}

B2.1. In hierdie gemeente getuig die ouderlinge en diakens se dienste van: \begin{tabular}{|l|c|c|c|}
\hline oneffektiwiteit en gebrek aan toewyding & JA & SOMS & NEE \\
\hline
\end{tabular}

\begin{tabular}{|l|l|l|l|}
\hline 'n getrouheid aan gevestigde gewoontes & JA & SOMS & NEE \\
\hline vernuwende denke & JA & SOMS & NEE
\end{tabular}

\begin{tabular}{|c|c|c|}
\hline $\begin{array}{l}\text { Die term gawes beteken die natuurlike vermoëns } \\
\text { in elke mens waarby die medemens kan baat, bv. } \\
\text { diensvaardigheid, voorbidding, gasvryheid, leierskap, ens. }\end{array}$ & $J A$ & NEE \\
\hline \multicolumn{3}{|l|}{ B3. In hierdie gemeente word die gelowige: } \\
\hline $\begin{array}{l}\text { doelbewus deur die kerkraad gelei dat elkeen } \\
\text { sy/haar eie gawes kan ontdek en ken }\end{array}$ & $J A$ & NEE \\
\hline $\begin{array}{l}\text { doelbewus deur die kerkraad gehelp/bemagtig om } \\
\text { sy/haar eie gawes te ontwikkel }\end{array}$ & $J A$ & NEE \\
\hline \multicolumn{3}{|l|}{ B3.1. In die gemeente is die diens/amp van die gelowige: } \\
\hline $\begin{array}{l}\text { net so aktief soos die diens/amp van die diaken en die } \\
\text { ouderling }\end{array}$ & $J A$ & NEE \\
\hline $\begin{array}{l}\text { aktief volgens elkeen se eie uitlewing in sy/haar } \\
\text { persoonlike lewe }\end{array}$ & $J A$ & NEE \\
\hline
\end{tabular}

B3.2. Binne jou gemeente word (geestelike) gawes by elke gelowige versigtig hanteer: \begin{tabular}{|l|c|c|}
\hline omdat dit nie gereformeerd is nie & WAAR & ONWAAR \\
\hline omdat dit dwaling in die kerk kan inbring & WAAR & ONWAAR \\
$\begin{array}{l}\text { omdat dit moeilik is om elkeen met sy eie gawes } \\
\text { in die kerk te laat optree }\end{array}$ & WAAR & ONWAAR \\
\hline
\end{tabular}

\begin{tabular}{|l|c|c|}
\hline B3.3. Opbou en doel van opbou binne die gemeente: & NEE \\
\hline $\begin{array}{l}\text { In hierdie gemeente word elke lidmaat deur die } \\
\text { bediening geestelik opgebou }\end{array}$ & JA & NEE \\
\hline $\begin{array}{l}\text { In hierdie gemeente word elke lidmaat opgebou sodat } \\
\text { hy/sy ander mense buite die gemeente maklik kan } \\
\text { evangeliseer }\end{array}$ & JA & NEE \\
\hline $\begin{array}{l}\text { In hierdie gemeente word elke lidmaat bemagtig sodat } \\
\text { hy/sy ander mense oor die kleurgrens maklik kan } \\
\text { evangeliseer }\end{array}$ & JA & \\
\hline
\end{tabular}
evangeliseer

C. Maak langs elke stelling ' $n$ kruisie in die toepaslike blokkie volgens jou oortuiging

\begin{tabular}{|c|c|c|c|}
\hline \multicolumn{4}{|c|}{ C1. Is daar in die dorp/stad waar jou gemeente is, 'n kerkgebou vir: } \\
\hline \multicolumn{2}{|l|}{ die NG Kerk } & JA & NEE \\
\hline \multicolumn{2}{|l|}{ die Nederduitsch Hervormde Kerk } & $J A$ & NEE \\
\hline \multicolumn{2}{|l|}{ die Gereformeerde Kerk } & $J A$ & NEE \\
\hline \multicolumn{4}{|c|}{ C2. Bewussyn van krimping in die drie susterkerke: } \\
\hline $\begin{array}{l}\text { a. Volgens jou beste wete het die NG Kerk } \\
\text { in jou dorp/voorstad in getalle gekrimp }\end{array}$ & $J A$ & ONSEKER & NEE \\
\hline $\begin{array}{l}\text { b. Volgens jou beste wete het die NH Kerk } \\
\text { in jou dorp/voorstad in getalle gekrimp }\end{array}$ & $\mathrm{JA}$ & ONSEKER & NEE \\
\hline $\begin{array}{l}\text { c. Jou eie gemeente het ook as gevolg van } \\
\text { verskillende redes gekrimp }\end{array}$ & $J A$ & ONSEKER & NEE \\
\hline
\end{tabular}

\begin{tabular}{|l|c|c|}
\hline \multicolumn{2}{l|}{} & \multicolumn{2}{l|}{} \\
\hline C3. Die fisiese kerkgebou is vir jou as gelowige: & JA & NEE \\
\hline 'n anker in veranderende tye & JA & NEE \\
\hline $\begin{array}{l}\text { 'n emosimbool van waardes en norme } \\
\text { verkoop moet word weens krimpende getalle }\end{array}$ & JA & NEE \\
\hline $\begin{array}{l}\text { van so 'n aard dat as die kerkgebou verkoop word, } \\
\text { die gemeente ook eintlik ten gronde gaan }\end{array}$ & JA & NEE \\
\hline $\begin{array}{l}\text { 'n lanseerplek' van projekte na die wêreld toe in } \\
\text { diens van evangelisasie }\end{array}$ & JA & NEE \\
\hline
\end{tabular}

C4. Waar jy in die gemeente is, is die gemeentestrukture: deur die jare gevestig die vaste vorm wat sekerheid gee aan gemeentelede

\begin{tabular}{|l|l|}
\hline JA & NEE \\
\hline JA & NEE \\
\hline
\end{tabular}

C4.1. Strukture (soos die finansiële sisteem, die kerkstruktuur, organisasiewyses en kerkprogramme) binne jou gemeente:

\begin{tabular}{|l|c|c|}
\hline word gedurig verander en aangepas & JA & NEE \\
\hline $\begin{array}{l}\text { word as vaste sekerhede beskou wat deur die jare al } \\
\text { suksesvol bewys is, al is dit soms lomp in funksionering }\end{array}$ & JA & NEE \\
\hline
\end{tabular}

suksesvol bewys is, al is dit soms lomp in funksionering

\section{Maak langs elke stelling ' $n$ kruisie in die toepaslike blokkie volgens jou oortuiging}

D1. ' $n$ Leier in die gemeente is:

die predikant

persone in ampte (ouderlinge/diakens)

Noem asb. ander leiers in jou gemeente 


\begin{tabular}{|l|c|c|}
\hline D2. Die geestelike leiers in die gemeente se taak is om: \\
\hline $\begin{array}{l}\text { die gemeente aan te moedig dat die kerklike program } \\
\text { slaag }\end{array}$ & JA & NEE \\
\hline $\begin{array}{l}\text { die gemeente doelbewus aan te moedig om hul gawes } \\
\text { te ontdek en te ontwikkel }\end{array}$ & JA & NEE \\
\hline die gemeente doelbewus geestelik op te bou & JA & NEE \\
\hline $\begin{array}{l}\text { die gemeente doelbewus toe te rus om buite die } \\
\text { gemeente te kan evangeliseer }\end{array}$ & JA & NEE \\
\hline
\end{tabular}

\section{D3. Die leiers in jou gemeente se ingesteldheid kan beskryf word:}

\begin{tabular}{|l|c|c|}
\hline $\begin{array}{l}\text { as diegene wat die 'gereformeerde skoppelmaai' laat } \\
\text { swaai }\end{array}$ & JA & NEE \\
\hline $\begin{array}{l}\text { as identifiseerders van probleemareas binne die } \\
\text { gemeente }\end{array}$ & JA & NEE \\
\hline as Woordgesentreerd & JA & NEE \\
\hline $\begin{array}{l}\text { as missionêr (met ander woorde die leiers se optrede } \\
\text { word gerig deur sending/evangelisasie) }\end{array}$ & JA & NEE \\
\hline as voorlopers met vernuwende perspektiewe & JA & NEE \\
\hline as interpreteerders van die huidige tydsgewrig & JA & NEE \\
\hline
\end{tabular}

\begin{tabular}{|l|c|c|}
\hline D4. Is die volgende ' $n$ bekende siening in jou gemeente: \\
\hline $\begin{array}{l}\text { Die leiers is bewus van God se plan in die gemeente en } \\
\text { spoor die gemeente aan om saam daaroor te dink }\end{array}$ & JA & NEE \\
\hline
\end{tabular}

\begin{tabular}{|l|c|c|c|}
\hline D5.1. Jou siening van die predikant as leier is: \\
\hline dat hy vervul is met die Heilige Gees & ALTYD & SOMS & NOOIT \\
\hline dat hy formalisties is & ALTYD & SOMS & NOOIT \\
\hline $\begin{array}{l}\text { dat hy onbetrokke lidmate onvermydelik } \\
\text { as deel van die sisteem aanvaar }\end{array}$ & ALTYD & SOMS & NOOIT \\
\hline dat hy missionêre bediening bevorder & ALTYD & SOMS & NOOIT \\
\hline dat hy lidmate bemagtig & ALTYD & SOMS & NOOIT \\
\hline $\begin{array}{l}\text { dat hy in sy werksprogram bygestaan/ } \\
\text { gehelp word deur sommige gemeentelede }\end{array}$ & ALTYD & SOMS & NOOIT \\
\hline $\begin{array}{l}\text { dat die gemeente meen die predikant } \\
\text { behoort van alles op hoogte te wees }\end{array}$ & ALTYD & SOMS & NOOIT \\
\hline dat hy sy eie mening deurdruk & ALTYD & SOMS & NOOIT \\
\hline $\begin{array}{l}\text { dat hy streng, formalisties en selfs } \\
\text { diktatoriaal is }\end{array}$ & ALTYD & SOMS & NOOIT \\
\hline
\end{tabular}

E. Maak langs elke stelling ' $n$ kruisie in die toepaslike blokkie volgens jou oortuiging

E1. Die siening van die predikant as prediker soos waargeneem deur jou is:

\begin{tabular}{|l|c|c|c|}
\hline $\begin{array}{l}\text { dat hy moeite doen met } \\
\text { preekvoorbereiding }\end{array}$ & ALTYD & SOMS & NOOIT \\
\hline dat die prediking relevant is & ALTYD & SOMS & NOOIT \\
\hline $\begin{array}{l}\text { dat die prediking verveling en minimum } \\
\text { groei in die hand werk }\end{array}$ & ALTYD & SOMS & NOOIT \\
\hline $\begin{array}{l}\text { dat die vaste liturgie sekerheid } \\
\text { bewerkstellig in die erediens }\end{array}$ & ALTYD & SOMS & NOOIT \\
\hline dat by tradisie en gebruike gehou word & ALTYD & SOMS & NOOIT \\
\hline $\begin{array}{l}\text { dat hy toegerus is om die huidige } \\
\text { veranderende tydsgewrig te verwerk }\end{array}$ & ALTYD & SOMS & NOOIT \\
\hline dat prediking entoesiasties geskied & ALTYD & SOMS & NOOIT \\
\hline
\end{tabular}

E2.1. Jou gemeente se eredienste, soos wat ' $n$ vreemdeling dit sou waarneem, is:

\begin{tabular}{|l|c|c|}
\hline $\begin{array}{l}\text { 'n byeenkoms wat getuig van 'n vriendelike, spontane } \\
\text { atmosfeer }\end{array}$ & JA & NEE \\
\hline $\begin{array}{l}\text { 'n byeenkoms wat getuig van deelname/aktiwiteit deur } \\
\text { hoofsaaklik die predikant }\end{array}$ & JA & NEE \\
\hline $\begin{array}{l}\text { 'n byeenkoms wat getuig van gevestigde tradisie en } \\
\text { stigtelikheid }\end{array}$ & JA & NEE \\
\hline 'n byeenkoms wat fokus op die Woord & JA & NEE \\
\hline 'n byeenkoms wat getuig van geestelike inspirasie & JA & NEE \\
\hline 'n byeenkoms wat getuig van byderwetse gebruikstaal & JA & NEE \\
\hline $\begin{array}{l}\text { 'n byeenkoms wat getuig van onderlinge stramheid } \\
\text { weens verdeeldheid (bv. as gevolg van kwessies oor } \\
\text { psalmberymings/omdigtings, vrou in die amp, kelkie- } \\
\text { gebruik, ens.) }\end{array}$ & JA & NEE \\
\hline
\end{tabular}
gebruik, ens.)

F. Maak langs elke stelling ' $n$ kruisie in die toepaslike blokkie volgens jou oortuiging

F1. Die term kleingroepe word soos volg verstaan:

\begin{tabular}{l|l|l|}
$\begin{array}{l}\text { In die gemeente waar jy lidmaat is, is die term } \\
\text { kleingroepe bekend as deel van die bedieningsplan }\end{array}$ & JA & NEE \\
\hline
\end{tabular}
F2. In die gemeente waar jy is, word kleingroepe: gebruik om die individuele lidmaat as volle mens makliker te bereik

gebruik om te help om gawes by elke individu te ontdek verkeerd gebruik want dit fokus oormatig net op die mens se behoeftes

gebruik om bemagtiging en opbou in die gemeente te vergemaklik

gebruik om die individu te bemagtig om na buite uit te reik

om die individu binne ' $n$ intieme groep geborge/veilig te laat voel

\begin{tabular}{|c|c|}
\hline JA & NEE \\
\hline JA & NEE \\
\hline JA & NEE \\
\hline JA & NEE \\
\hline JA & NEE \\
\hline
\end{tabular}

F3. In jou gemeente is die volgende groepe deel van die (kleingroep) bediening: waar Bybelstudie gedoen word waar enkellopendes byeenkom

waar geskeides byeenkom

waar enkelouers byeenkom

waar tieners byeenkom

waar jong werkendes/studente byeenkom

waar seniors byeenkom

Noem enige ander (klein) groep(e) wat in jou

gemeente funksioneer

\section{G. Maak langs elke stelling ' $n$ kruisie in die toepaslike blokkie volgens jou oortuiging}

G1. Die term dissipelskap as kerktaal:

\begin{tabular}{|l|l|l}
\hline Die term dissipelskap is tradisionele kerktaal binne jou & JA & NEE
\end{tabular} gemeente.

\begin{tabular}{|l|c|c|}
\hline \multicolumn{2}{|l|}{ G2. Die term evangelisasie is: } \\
\hline $\begin{array}{l}\text { eintlik onbekend aan my want ek weet nie wat dit alles } \\
\text { behels nie }\end{array}$ & JA & NEE \\
\hline nie deel van die gereformeerde identiteit nie & JA & NEE \\
\hline $\begin{array}{l}\text { 'n kerksaak wat gewoonlik deur 'n kommissie behartig } \\
\text { word }\end{array}$ & JA & NEE \\
\hline $\begin{array}{l}\text { om die mense wat kerklos is in hul geestelike nood } \\
\text { tegemoet te kom en terug te bring kerk toe }\end{array}$ & JA & NEE \\
\hline $\begin{array}{l}\text { om mense in hulle sosiale omstandighede en fisiese } \\
\text { nood tegemoet te kom }\end{array}$ & JA & NEE \\
\hline $\begin{array}{l}\text { Sending is evangelisasie wat ver, weg van die gemeente } \\
\text { af, plaasvind }\end{array}$ & JA & NEE \\
\hline
\end{tabular}
af, plaasvind

G3. Die groot opdrag (Gaan dan heen, maak dissipels van alle nasies en doop hulle in die Naam van die Vader en die Seun en die Heilige Gees):

word deur doelbewuste pogings in my gemeente

deur die predikant, die kerkleiers en die gemeente

gehoorsaam en uitgevoer.

NEE

H. Maak langs elke stelling ' $n$ kruisie in die toepaslike blokkie volgens jou oortuiging

H1 Dui aan hoe ' $n$ vreemdeling, volgens jou mening, heel moontlik sal voel as hy/sy die onderlinge samesyn in jou gemeente ervaar:

die onderlinge atmosfeer word as

liefdevol en vriendelik ervaar

die onderlinge verhoudings spreek van

aanvaarding, respek en geduld

die liefdesbeginsel wat opsigtelik oor die

kleurgrens strek

'n gevoel van liefde wat ervaar word

deurdat die gemeentelede eerste kontak

maak deur belangstelling, bekendstelling,

uitnodigings vir tuisbesoeke of ander

sosiale geleenthede

'n Afsydigheid wat aangevoel word en

wat spreek van geloofs-individualisme/

ingekeerdheid

'n Afsydigheid wat aangevoel word en

wat spreek van onderlinge verdeeldheid,

venyn en onvergewensgesindheid

\begin{tabular}{|c|c|c|c|}
\hline ALTYD & SOMS & NOOIT \\
\hline ALTYD & SOMS & NOOIT \\
\hline ALTYD & SOMS & NOOIT \\
\hline ALTYD & SOMS & NOOIT \\
\hline ALTYD & SOMS & NOOIT \\
\hline
\end{tabular}

regterkant vir die 1 tot 4 -skaal (1=Waar;

. Gebruik die blokkies aan die regterkant
2=Waarskynlik; 3=Onwaarskynlik; $4=$ Onwaar)

11. Die volgende landsomstandighede het ' $n$ invloed op jou denkwyse as gereformeerde gelowige.

Misdaad en vrees

Regstellende aksie en rassisme

Waarheids- en Versoeningskommissie se optrede

Materiële voorspoed wat emigrasie moontlik maak 
12. Gebruik dieselfde skaal en dui aan in hoe ' $n$ mate die volgende oor Afrikaanssprekende susterskerk-gelowiges, volgens jou denkwyse, ter sprake is:

\begin{tabular}{|l|l|l|l|l|}
\hline $\begin{array}{l}\text { Die susterskerk-gelowige onttrek van die openbare } \\
\text { terrein onder andere omdat die apartheidsgeskiedenis } \\
\text { teen hom tel }\end{array}$ & 1 & 2 & 3 & 4 \\
\hline $\begin{array}{l}\text { Die susterkerk-gelowige se invloed in die land verskuif } \\
\text { na die kant/periferie }\end{array}$ & 1 & 2 & 3 & 4 \\
\hline $\begin{array}{l}\text { Die susterskerk-gelowiges is volgens taal, geskiedenis } \\
\text { en belydenis een en behoort as eenvormige } \\
\text { kerkverband te funksioneer }\end{array}$ & 1 & 2 & 3 & 4 \\
\hline $\begin{array}{l}\text { Die Gereformeerde Kerke is te klein om betekenisvol in } \\
\text { die land op te tree }\end{array}$ & 1 & 2 & 3 & 4 \\
\hline $\begin{array}{l}\text { Die Gereformeerdes se huidige instelling is om die land } \\
\text { te help opbou }\end{array}$ & 1 & 2 & 3 & 4 \\
\hline $\begin{array}{l}\text { Die huidige Afrikaanssprekende gelowiges is sterk } \\
\text { individualisties }\end{array}$ & 1 & 2 & 3 & 4 \\
\hline $\begin{array}{l}\text { Die huidige Afrikaanssprekende gelowiges se } \\
\text { geloofsuitlewing is geloofwaardig in die oë van } \\
\text { andertaliges en onder ander gelowe }\end{array}$ & 1 & 2 & 3 & 4 \\
\hline $\begin{array}{l}\text { Die huidige Afrikaanssprekende gelowiges is besig om } \\
\text { n kultuurverandering te ondergaan }\end{array}$ & 1 & 2 & 3 & 4 \\
\hline Die huidige Afrikaanssprekendes is leierloos & 1 & 2 & 3 & 4 \\
\hline
\end{tabular}

13. Gebruik dieselfde skaal en dui aan hoe jy oor die volgende gesinsake dink: Ouers se lewenswyse is belangrik om die kinders vir die kerk te behou

Die generasiegaping is ' $n$ werklikheid in gereformeerde gesinne

Internet/kuberruimtes vervul ' $n$ behoefte by die opgroeiende gereformeerde geslag

Kerkbesoek deur die gesin word ook deur seisoenale faktore soos koue, reën, hittegolwe, ens. beïnvloed
14. Gebruik dieselfde skaal en dui aan hoe jy as gereformeerde oor die volgende prinsipiële sake dink:

Gereformeerdes is as gevolg van landsomstandighede

ontnugter en voel onverskillig teenoor godsdiens

Gereformeerdes beleef die groot opdrag as 'n lewende realiteit

Gereformeerdes reformeer daadwerklik

Gereformeerdes toon 'n Afrika-gerigtheid en 'n Afrikadienswilligheid

\begin{tabular}{|l|l|l|l|l|}
\hline e & 1 & 2 & 3 & 4 \\
\hline & 1 & 2 & 3 & 4 \\
\hline & 1 & 2 & 3 & 4 \\
\hline
\end{tabular}

Neem asb vrymoedigheid om enige saak in die kerkpraktyk van jou gemeente hieronder te noem. Dit kan bloot die stel van 'n saak wees, of 'n saak wat die kerkpraktyk bevoordeel of dalk benadeel.
Baie dankie

Phia van Helden (082 541 6388) 